\title{
Márta Asztalos
}

\section{Family Romances in William Faulkner's Absalom, Absalom!}

\author{
This paper examines narration and storytelling in William Faulkner's Absalom, Absa- \\ lom! Narration and storytelling are a paternal legacy and a family destiny as well, \\ which bind the son to the father and the Grandfather. However, they also become \\ the means of overwriting the paternal meta-narrative and endeavors of narrative \\ self-fathering, self-begetting. In this reading, the "story-weaving" of the narrators \\ and the story woven (by them) swirl around the same conflict: the "battle" of fathers \\ and sons. It is explored how these paternal-filial power relations and conflicts work \\ in both "layers" of the novel and how they influence each other. The argument will \\ build on the insights of Freudian and Lacanian psychoanalysis, especially the theory \\ of the Freudian family romance.
}

Faulkner, as critics like Richard P. Adams, Andre Bleikasten, ${ }^{1}$ or Lynn G. Levins have rightly observed, was obsessed with the questions of fatherhood, patriarchy, and the metaphor of the father as the key fantasy of the South. Almost all of his novels can be read, or even offer themselves to be read, as inquiries into the functions and malfunctions of fatherhood and father-son relationships. His world "abounds in orphans and bastards," 2 and "in at least four of his major novels - The Sound and The Fury, Light in August, Absalom, Absalom! and Go Down, Moses the father-son relationship is assuredly one of the crucial issues." 3

Moreover, Faulkner himself stated in an interview that Absalom, Absalom! one of his most important novels - is a "story of a man who wanted a son and got too many, got so many that they destroyed him." 4 Thus, it is a story of fathers and sons and their mutually dependent and mutually destructive existence. There is no

1. "[T] $]$ here is an abiding fascination with the question of fatherhood" (André Bleikasten, "Fathers in Faulkner," The Fictional Father: Lacanian Readings of the Text, ed. Robert Con Davis [Amherst: U of Massachusetts P, 1981], p. 120).

2. Bleikasten, p. 116.

3. Bleiksten, p. 120.

4. Frederick L. Gwynn and Joseph L. Blotner, Faulkner in the University (Charlottesville: UP of Virginia, 1995), p. 71.

The AnaChronisT 17 (2012/13) 181-206 ISSN 1219-2589 (print) ISSN 2063-126X (web) 


\section{MÁRTA ASZTALOS}

father without a son and no son without a father; however, the son not only creates the father 5 but also poses a threat to him with his very existence.

In spite of the fact that the story of Thomas Sutpen and his family is reconstructed and related not by his descendants, in the literal sense of the word, ${ }^{6}$ but by four narrators consanguineously unrelated to him, I claim that the novel can be looked at as a genealogical one, as all four narrators act as "genealogists," endeavoring to retrace the Sutpen family history and to fathom the mysterious murder through the enigmatic family relations. Moreover, the novel can be termed genealogical in another sense of the word as well: it seems that among the narrators in the Compson family, the story and the right of storytelling are family legacies handed down in the paternal line from grandfather (General Compson) to father (Mr. Compson) to son (Quentin). "It was part of his twenty years' heritage of breathing the same air and hearing his father talk about the man." 7 Thus, somewhat simplifying the matter, we can say that one of the main lines of story-transmission or story movement is also mainly patrilinear and genealogical.

As the story of the father(s) anterior in time is (re)constructed by the "sons," and since storytelling itself is not only a legacy but a family destiny as well, the story functions like a ritual thread which binds the son to the father, and through the father to the grandfather. In this way it strengthens paternal authority: the sons are subject to the story of the fathers' and to the obligation of storytelling. They are doomed to function like channels, as the story has to be told, the narration has to be continued.

On the other hand, as narrators they can overwrite or reconstruct/deconstruct the hereditary, paternal narrative and, through that, paternal authority itself. Thus, we can state that it is not only the Sutpen drama, the inner stage, ${ }^{8}$ or, to use Clifford E. Wulfman's expression, the "told layer," 9 of the novel that centers on paternal and filial conflicts but the "outer stage"10 or the "telling layer"11 as well. Thus, "story-

5. Fathering a son makes a father out of a man.

6. However, according to Patricia Tobin: Sutpen is the "father" for all the Southern narrators ... to the extent that they perceive the Sutpen family as a paradigm of the rise and fall, the virtues and defects, of the South, a paradigm which dominates their own self-definition. Patricia Tobin, Time and the Novel: The Genealogical Imperative (Princeton, N.J.: Princeton UP, 1978), p. 111.

7. William Faulkner, Absalom, Absalom! (New York: Vintage, 1990), p. 7.

8. Ilse Dusoir Lind, "The Design and Meaning of Absalom, Absalom!" PMLA 60 (1955) 887-912, p. 895 .

9. Clifford E. Wulfman, "The Poetics of Ruptured Mnemosis: Telling Encounters in William Faulkner's Absalom, Absalom!” Faulkner Journal 20.1-2 (2004-5) 111-132, p. 124.

10. Lind, p. 895. 
weaving" of the narrators, using Mieke Bal's concept the narrative text, and the story woven (by them), the story in Bal's terms, swirl around the same conflict. The "battle" of the fathers and sons takes place on many levels of the novel.

According to Bassett, "critical commentary on Absalom, Absalom! falls into two major categories," ${ }^{12}$ following the above-mentioned structural and temporal duality of the novel:

one focusing on the nineteenth-century story of Thomas Sutpen and the other emphasizing the twentieth-century dilemma of Quentin Compson. The first is concerned with the social themes, myth and legend, tragic form and character; the second deals with narrative techniques, epistemological issues, and the novel's connection through Quentin Compson, to the Sound and the Fury (1929). ${ }^{13}$

The two "layers" of the novel, however, are inseparably linked not only by their seemingly similar mode of operation but also by the fact that the story (the Sutpen drama) naturally would not exist but for the story-weaving (narration) and the "dramatists"14 who (re)construct, fabricate, and transmit the story. The two "layers" cannot be examined discretely, as the reader (or critic) gets to know the narrators only through the stories they tell. Moreover, the stories constructed cannot be detached from the narrators, their personalities, and motivations, the way they (are able to) comprehend and piece together the provided "factual" information, and the pattern they prefer to use in putting together the pieces. As Donald M. Kartiganer puts it: "each narrator tells the Sutpen story in accordance with his own private needs," ${ }^{15}$ using the act of narration as a way of self-articulation. ${ }^{16}$ Accordingly, anyone who sets out to examine the "outer" and "inner stage", the narrative text and the story separately, attempts the impossible and violates the novel in a rather unnatural and insensitive way.

Trying to act/write in accordance with the above presuppositions, I will attempt to give a comprehensive reading of Faulkner's Absalom, Absalom! examining how

11. Wulfman, p. 124.

12. John E. Bassett, "Absalom, Absalom: The Limits of Narrative Form." Modern Language Quarterly 46.3 (1985) 276-292, p. 276.

13. Bassett, p. 276.

14. Lind, p. 897.

15. Donald M. Kartiganer, The Fragile Thread: The Meaning of Form in Faulkner's Novels (Amherst: U of Massachusetts P, 1979) p. 71.

16. Ilse Dusoir Lind compares the performance of the three narrators (ignoring the importance of one of them) to that of three Greek dramatists "composing tragedies about the same mythical figure ... each spinning his version of the legend out of his own psyche" (Lind, p. 896). 


\section{MÁRTA ASZTALOS}

these paternal-filial power relations and conflicts work in both "layers" of the novel and how they influence each other. In my reading, I will make use of the insights of Freudian and Lacanian psychoanalysis, especially the theory of the Freudian Family Romance.

\section{The Four Narrators and the Three Narratives}

The Sutpen drama takes shape before the reader's eyes through the contribution of four narrators: Rosa Coldfield, Mr. Compson, Quentin Compson and Shreve MacCannon with united efforts. All the four narrators approach the story material from different perspectives and with different dispositions, in consequence of which they come to very diverse conclusions concerning the major enigmas that trigger the story: the reason behind Henry Sutpen's repudiation of his father on the Christmas Eve of 1860 for his college friend Charles Bon; and the motivation behind his murdering the very same man at the gates of Sutpen's Hundred four years later.

\section{Rosa Coldfield and the Initial Lack}

Rosa, the first in the line, is unique among the narrators, being the only homodiegetic one with firsthand experience. Although some critics claim her to be an "inadequate,"17 "impotent,"18 "both physically and psychically misshapen,"19 "near-hysterical," sets the story in motion, motivating the other narrators (Quentin directly, and the others indirectly) to solve the enigma, to weave the diverging and sporadic information about the Sutpen family into a consistent, linear narrative. Thus, she launches in the novel what Patricia Tobin calls the genealogical imperative: "[A]ll possibly random events and gratuitous details are brought into an alignment of relevance, so that at the point of conclusion all possibility has been converted into necessity within a line of kinship - the subsequent having been referred to the prior, the end to the beginning, the progeny to the father., ${ }^{21}$

17. Richard C. Moreland, Faulkner and Modernism: Rereading and Rewriting (Madison: U of Wisconsin P, 1990) p. 27.

18. Eric Sundquist, "Absalom, Absalom! and the House Divided," in William Faulkner's Absalom, Absalom! ed. Fred Hobson (Oxford, England: Oxford UP, 2003) 107-49, p. 112.

19. Lind, p. 891.

20. Kartiganer, p. 76 .

21. Tobin, pp. 7-8. 
Many critics who aim at coupling the four narrative perspectives with different literary genres, such as Richard P. Adams, ${ }^{22}$ Lynn G. Levins, ${ }^{23}$ John E. Bassett, ${ }^{24}$ and Philip J. Egan, ${ }^{25}$ claim that her narrative operates in the Gothic mode. She attributes "larger than life proportions" and "supernatural powers" 26 to the characters, especially to Thomas Sutpen, taking him for a "demon"(Faulkner 8), "an ogre or a djinn" (16). Abruptness of action, illogicality, and lack of causality (or magical causality) characterize her narrative. Her narratee, Quentin also points this out, reflecting upon her "telling"/narration that it has the "logic- and reason-flouting quality of a dream" (15). She just recounts the events she witnessed (and also those she only heard of), admitting that she does not understand the reason or motivation behind them: "I saw Henry repudiate his home and birthright and then return and practically fling the bloody corpse of his sister's sweetheart at the hem of her wedding gown" "without rhyme or reason or shadow of excuse" (12). As Peter Brooks puts it, she offers "a completely nonhermeneutic narrative" with "no structure of meaning for the sequence of events." ${ }^{27}$ Consequently, I would state that her deficiency of understanding and her narrative's lack of causality constitute that initial lack which needs to be there in the beginning of every narrative, the vacuum of which calls for filling in and, thus, triggers storytelling. Her not knowing provides the mystery that launches the hermeneutic quest, since the subsequent narrators try to patch this hole in the cloth of the narrative, providing different justifications, revealing different, up to that point, hidden or nonexistent information.

\section{Mr. Compson and His Fatalistic Romance}

Mr. Compson, the next narrator in the line, is the one who starts coloring Rosa's rather black and white, "somewhat" extremist picture. He reshapes the figure of Thomas Sutpen, Miss Rosa's rather demonic and demiurgic villain, who becomes the self-made American hero of Mr. Compson's narrative. He also tries to come up with a logical explanation concerning the central enigmas of the novel and "starts out ... with confidence in his ability to understand the past and tell the story of 181.

22. Richard P. Adams, Faulkner: Myth and Motion. (Princeton, N.J: Princeton UP, 1968)

23. Lynn G. Levins, "The Four Narrative Perspectives in Absalom, Absalom!" PMLA 85 (1970) 35-47, p. 36.

24. Bassett, p. 38.

25. Philip J. Egan, "Embedded Story Structures in Absalom, Absalom!" American Literature 55 (1983) 199-214, p. 199.

26. Bassett, p. 37.

27. Peter Brooks, "Incredulous Narration: Absalom, Absalom!" Comparative Literature 34 (1982) 247-68, p. 250. 


\section{MÁRTA ASZTALOS}

Sutpen."28 According to him, Henry's reason for murdering Bon was the latter's intended bigamy, since he already has an octoroon wife and a son in New Orleans, kept secret. In Mr. Compson's version, this is the information that Sutpen had found out and exposed to Henry on the ominous Christmas day, causing Henry's to repudiate him and leave Sutpen's Hundred with Bon the very same night. Four years later the same fact, plus Bon's unwillingness to renounce the other woman and the child, were the reasons of Henry's murdering the man for the sake of whom he had given up everything.

There seems to be a consensus among critics that Mr. Compson constructs his story in the pattern of classical Greek tragedies and epics. ${ }^{29}$ I do agree with these critics that some elements of his narrative resemble those of the Greek tragedies, such as Sutpen's introduction, the epic proportions, and the crucial importance he attributes to "the machinations of a fatality" (81). Fatality is, indeed, one of the two most important characteristics of his narrative. He claims, at several points in the novel, that the tragic events were "instigated by that family fatality which possessed, along with all circumstance, that curious lack of economy between cause and effect which is always a characteristic of fate when reduced to using human being for tools, material" (94).

Besides being the result of his laying great emphasis on the machinations of fate in recounting the story, I maintain that the fatal overtone of his narrative is also due to his narrative technique. He often constructs his narratives in a spiral, opening the story with the effect, the final tragic outcome, $3^{\circ}$ and going back only after that to relate the cause, the events leading up to it. Moreover, he keeps revisiting the tragic ending in references and flash-forwards. For example, in Chapter IV, his narrative starts spiraling between Bon's Christmas Eve visit to Sutpen's Hundred and the next, final time he ever gets close to the gates of the Sutpen mansion:

Because Henry loved Bon. He repudiated blood birthright and material security for his sake, for the sake of this man who was at least an intending bigamist even if not an out and out blackguard, and on whose dead body four years later Judith was to find the photograph of the other woman and the child ... he and Bon rode side by side through the iron dark of that Christmas morning, away from the house where he had been born and which he would see but one time more and that with the fresh blood of the man who now rode beside him, on his hands... $\quad$ (71, my emphasis)

28. Margaret Dickie Uroff, "The Fictions of Absalom, Absalom!" Studies in the Novel 11 (1979) 431-45, p. 435.

29. Kartiganer, p. 78. Adams, p. 181. Bassett, p. 39.

30. For example with a tombstone in his last narrative. 
The other hallmark of his narrative is the major role assigned to love and romance. He constructs his story along the lines of male-female relationships: BonJudith, Bon-the octoroon, provoking the required conflict in the plot by intersecting them. Moreover, he hints at romantic attachment in both cases: "he [Bon] loved her [Judith]" (102), "a woman with a face like tragic magnolia, the eternal female" (91), "the woman and the child that Bon would not renounce" (94). Actually, to be more precise, instead of constructing two mutually exclusive, linear, one-to-one love relationships; he constructs two "love-triangles": an Oedipal triad, Bon - the octoroon - their son (Charles Etienne de St. Valery Bon); and an incestuous one, Bon - Judith - Henry. He keeps emphasizing the motive of incest or the presence of incestuous attraction between Henry and Judith:

In fact, perhaps this is the pure and perfect incest: the brother realizing that the sister's virginity must be destroyed in order to have existed at all, taking that virginity in the person of the brother-in-law, the man whom he would be if he could become, metamorphose into, the lover, the husband...

The two "love-triangles" drawn by Mr. Compson, actually, work quite similarly in terms of how desire functions, how it is barred and gets resolved through a substitution. In Freud and Lacan, the fundamental desire is the incestuous desire for the mother, the primordial Other ${ }^{31}$ The child (son) desires the mother and wants to become her object of desire; the circuit of mutual desire between mother and child is broken with the intervention of the father, who makes the child abandon his desire for the mother and substitute it for the Name-of-the-Father, which leads to the dissolution of the Oedipus complex. Through a symbolic identification with the father, the child accepts "substitution" and lets go of the mother, "giving her over" to the father.

In Henry and Judith's case, we can perceive something very similar: Henry cannot commit incest in the literal sense of the word, in spite of the fact that he, according to Mr. Compson at least, would love to. He is, thus, ready to "commit" it through substitution, through an identification with the "rival." He lets go of Judith, giving her over to Bon. However, the situation is made even more exciting, since Henry is ready to choose Bon not only as a substitute, as a "rival," who would "despoil" the sister instead of him, but as his own "despoiler" as well if only "he could metamorphose into the sister, the mistress, the bride" (77). His affection and unconditional love for Bon are often portrayed as bordering on homoeroticism: "Because Henry loved Bon" (71), "Yes, he loved Bon, who seduced him" (76). Quite a number of critics, like John T.

31. Jacques Lacan, The Seminar of Jacques Lacan: Book VII. The Ethics of Psychoanalysis, ed. Jacques-Alain Miller, trans. Dennis Porter (London: Routledge, 1992), p. 67. 


\section{MÁRTA ASZTALOS}

Irwin, Ilse Dusoir Lind, etc. assign Henry's homoerotic attraction to Bon to Quentin or/and Shreve's similar tendencies. John T. Irwin states that "the latent homoerotic content in the story of Bon and Henry may well be the projection of Quentin's own state made in the act of narration." 32 On the other hand, Ilse Dusoir Lind argues that "Shreve ... projects the fraternal affection, mildly homosexual in basis, which exists between his roommate and himself." 33 However, we need to notice that it is Mr. Compson who starts inscribing this thread into the narrative; Quentin and Shreve only take up the thread and weave it on. This initiative of Mr. Compson is, in fact, made necessary by the fact that he tries to "rationalize" everything with "love," and malefemale affection (Bon's supposed affection for Judith) is not able to account for most of the events of the plot. "Love" in his narrative works quite similarly to "the machinations of a fatality" (102). Whatever he is not able to give a logical explanation to, he attributes to "love." As Robert Dale Parker puts it, "it's easy enough and maybe even plausible enough for him to write off as love what he doesn't understand." 34

Thus, fatality and love are the patches that he uses in an attempt to cover the gaps remaining. ${ }^{35}$ In other words, he tries to make a hermeneutic clue from the lack of those, tries to pass off the lack of a motive as a motive. Moreover, on the surface, he manages to do this quite successfully, as Peter Brooks points out: he ends up having a "complex, intricate, seemingly highly motivated plot." 36 However, he himself acknowledges the discrepancies: "It's just incredible. It just does not explain" (80). However, pretending that everything is apt, he short-circuits the problem by stating that: "Or perhaps that's it: they don't explain and we are not supposed to know" (80). Hence, the story-triggering, narrative-provoking lack, having been imputed to "that curious lack of economy between cause and effect which is always a characteristic of fate" (94), remains exactly where it was, calling for further storytellers.

\section{Quentin Compson and the Proliferation of Romances}

Quentin, both previous narrators' patient audience, takes over the thread of the story from his father and continues reconstructing the past, trying to fit together the pieces of the puzzle. As Quentin joins the line of narrators, the Sutpen drama takes

32. John T. Irwin, Doubling and Incest/Repetition and Revenge: A Speculative Reading of Faulkner (Baltimore: John Hopkins UP. 1996) p. 78.

33. Lind, p. 892.

34. Robert Dale Parker, Absalom, Absalom! The Questioning of Fictions (Boston: Twayne, 1991) p. 52.

35. For example his version does not offer any acceptable explanation concerning Henry's four-year delay.

36. Brooks, p. 255. 
another, renewed shape. He relies on story patterns different from those of the previous narrators and approaches the story from a radically different viewpoint, which is his own perspective: the perspective of a son.

Referring to his perspective is, however, not totally valid, as he relates his story to his college roommate, Shreve MacCannon, who, at quite an early point, changes from passive audience to active participant in the narration. From that point on, they construct the story as "sons," in brotherly unison.

Quentin starts his narrative in the same pattern as the previous narrators did: reshaping the figure of the Father, Thomas Sutpen. From his/their narration the reader gets another radically different picture of the Father. He draws the figure of the old Sutpen. While Rosa created an all-powerful demon, almost the devil himself, and Mr. Compson shaped the self-made American hero, a "conquistador," who "turned his back upon all that he knew ... and ... set out into a world which even in theory ... he knew nothing about;" he/they formulate the figure of a "mad impotent old man who realized at last that there must be some limit even to the capabilities of a demon for doing harm," an "old wornout cannon" $(40,148)$. They dethrone the omnipotent Father, the great general, showing him in his utmost misery: "running his little country store now for his bread and meat" (149), degrading himself to seducing Milly Jones, the fifteen-year-old granddaughter of his tenant in desperate hope for a male heir. Thus, we can rightly say that they start their narrative with a symbolic castration and murder of the father. Moreover, they perfect the picture with a literal patricide as well, recounting the murder of Sutpen in detail, a description unworthy of a colonel.

Having read the first twenty pages of their narrative, the reader can rightly have the impression that they are obsessed with the figure of the Father. This anticipation is justified as one reads on, since having related the story of Charles Étienne SaintValéry Bon (Charles Bon's son whom Judith "adopts", having learned about the octoroon's death), Quentin "exhumes" the Father and goes on to recount the story of Sutpen's childhood to Shreve and the reader. This is the first time in the novel when Sutpen's character is shaped like a human figure and not like a demon, a superhuman hero, a monster, or a freak. Probably it is not accidental that this human figure is a son.

However, Quentin's obsession with the figure of the Father is not exhausted with recounting the story of how the son became (or endeavored to become) a Father, but appears as a proliferation of Oedipal threads and romances on the thematic level of the novel. Quentin and Shreve inscribe several real and imaginary sons and fathers into the story and attribute all dramatic situations to some kind of paternal-filial tension. I also argue that the inscribed Oedipal threads strongly resemble the pattern of the Freudian family romance, which not only can be detected in 


\section{MÁRTA ASZTALOS}

all threads that the Quentin/Shreve narrational function introduces but works as the main structuring device.

The "family romance," according to Freud, is a common fantasy among children, which, with neurotics, may reappear in later life as well. "Small events in the child's life which make him dissatisfied afford him provocation for beginning to criticize his parents... . [T] he child's imagination becomes engaged in the task of getting free from the parents of whom he now has a low opinion and of replacing them by others, who, as a rule, are of higher social standing." 37

In his article "Children of the Idea: Heroes and Family Romances in Absalom, Absalom!" T. H. Adamowski examines the novel from the perspective of the Freudian family romance and Otto Rank's concept of the hero. He states that "Sutpen's desire is structured in such a way by the narrative" that it is reminiscent of the Freudian family romance. $3^{8}$ He provides a detailed examination of Sutpen's life story from the given perspectives. Moreover, he proclaims that Bon and Henry also act out different aspects of the family romance as "Sutpen's experience haunts that of his children and they repeat various aspects of it, almost compulsively." 39 However, he attributes the inscription of the family romances to Quentin and Shreve in a rather vague manner in one single sentence: "The account offered by Shreve and Quentin of the family reunion begins to suggest romances within romances." $40 \mathrm{He}$ suggests that it is worth considering Quentin and Shreve's conjecture in the light of the family romance, however, he does not exploit the possibilities of the idea: he tries to understand neither their "conjecture" nor the act of "conjuring" in the suggested "light." He only comes to the conclusion that Quentin "does become fascinated with the "other family" and states that "Faulkner's many references to Shreve and Quentin as being 'both of them,' Henry and Bon, must inevitably suggest identification." 41

I consider the direction outlined by Adamowski more than valid. Moreover, I would claim that Quentin's obsession with paternity and paternal authority is not only evident if one reads the narratives constructed by him and Shreve, but is crucial in understanding his main motivation for storytelling. I also argue that the family romance fantasy is not only a recurring, constitutive element of Quentin and Shreve's "conjecture," playing a crucial role in working through father-son

37. Sigmund Freud, "Family Romances," in The Standard Edition of the Complete Psychological Works of Sigmund Freud, Vol. 9 (London: Vintage, 2001), 236-41, pp. 237-39.

38. T. H. Adamowski, "Children of the Idea: Heroes and Family Romances in Absalom, Absalom!" Mosaic 10 (1976) 115-31, p. 117.

39. Adamowski, p. 129.

40. Adamowski, p. 125.

41. Adamowski, p. 127. 
relationships and the anxieties present in them, but that the final stage of the romance (desire of self-fathering) functions as the main motivation behind their act of "conjuring."

John T. Irwin also gives a psychoanalytically informed reading of The Sound and the Fury and Absalom, Absalom! In his article entitled "The Dead Father in Faulkner," he comes a lot closer to considering Quentin and Shreve's "conjecture" from a similar perspective, in spite of the fact that he does not operate with the concept of the Freudian family romance in his text. In his study, he brings together Nietzsche's ideas about the nature of time ${ }^{42}$ and Freud's notion of the repetition compulsion with the concepts of fathering and filiation. He states that a son's fate is determined by that of his father's "because to come after is to be fated to repeat the life of another rather than live one's own." 43 In consequence of this, a son is also "fated" to struggle against his father and against time. Thus, Irwin comes to the conclusion that, for Quentin, the act of narrating the Sutpen story becomes a similar struggle against the nature of time and his father, "in which he tries to best his father" and "seize 'authority' by achieving temporal priority" to him in the narrative act.44 His struggle is to transform repetition as a compulsion or a fate into repetition as "a means of achieving mastery" over time. 45 Freud refers to this "mastery through repetition" as revenge with two major elements: repetition and reversal - one repeats the traumatic situation but reverses the roles. When there is no chance of taking revenge on the one who delivered the affront, the revenge is inflicted on a substitute (quoted in Irwin). Following this idea, Irwin also argues that through the act of narration, Quentin endeavors to take revenge against his father on a substitute - his roommate Shreve.

I do not see how Quentin could achieve temporal priority in the narrative act; however, I do agree with Irwin's claim that Quentin's main motivation to tell the story is closely connected to his desire to "best his father." Moreover, I claim that storytelling is not only a family destiny, a dynastic inheritance to which Quentin subjugates himself, but a way, or, rather, the only way, through which he can "walk[..] out of his father's talking at last" (142): it is his only chance to grow up, to "walk out of" paternal authority. His telling the story is an attempt to overwrite (cancel out) the paternal meta-narrative, thus an endeavor of narrative patricide

42. "[E]very moment in it exists only insofar as it has just consumed the preceding one, its father, and then is immediately consumed likewise" (Irwin, "Dead Fathers," p. 145).

43. Irwin, John T. "The Dead Father in Faulkner," in The Fictional Father: Lacanian Readings of the Text, ed. Robert Con Davis (Amherst: U of Massachusetts P. 1981), 147-68, p. 148.

44. Irwin, "Dead Father," p. 152.

45. Irwin, "Dead Father," p. 152. 


\section{MÁRTA ASZTALOS}

and self-fathering. In the following, I will attempt a close reading of the family romances inscribed by Quentin and Shreve and an examination of the extent to which they can serve Quentin in his attempt at self-fathering.

\section{When the Father was a Son: the Family Romance of Thomas Sutpen}

The first story that Quentin recounts is that of Sutpen's childhood ${ }^{46}$ and the birth of his "design." We get to know from him that Sutpen was ten when his family, following his father's abrupt decision, left their home in the Virginia mountains and set out towards new frontiers. Together with the family's journey, the boy Sutpen's initiation also started. He is presented primarily as a son, suffering a series of disappointments in his father and, consequently, losing faith in him. Since on the journey towards their new home, he has to witness his father degrading himself, right in front of his children and strangers as well, at almost every tavern on the way, where "the old man was not even allowed to come in by the front door and from which his mountain drinking manners got him ejected before he would have time to get drunk good" (183). When they finally settle down, his father starts working at a plantation where the owner makes a huge impression on the young Sutpen. He starts looking at the plantation owner as an ideal, a model and adopts him "as his surrogate father." ${ }^{47}$ As T. H. Adamowski and André Bleikasten ${ }^{48}$ also observe, at this point Sutpen's story starts to show an uncanny resemblance to the Freudian family romance. Even the surrogate father's occupation fits the Freudian scheme: of Freud's two examples to illustrate higher social standing, one is "the Lord of the Manor," 49 whom Sutpen chooses as an imaginary father. ${ }^{\circ}$

Other critics, like John T. Irwin, and, in his footsteps, Carolyn Porter, also point out the importance of choosing an ideal father and deciding "to become him" in the birth of Sutpen's design, however, they do not draw on Freud's family romance fantasy when examining Sutpen's behavior. ${ }^{51}$ Both of them use Freudian psychoa-

46. Henceforth I will refer to Thomas Sutpen as "Sutpen" and to Henry Sutpen as "Henry." 47. Irwin, "Dead Father," p. 154.

48. "His career begins like any other Oedipal 'family romance' " (Bleikasten, p. 139.).

49. Freud, "Family Romances," p. 239.

50. Faulkner could actually have read Freud's "Family Romances," as the article's first English translation appeared in Otto Rank's Myth of the Birth of the Hero in 1913, and he started working on the novel in 1933 (Ursula Brumm, "William Faulkner and the Southern Renascence," in American Literature Since 190o, ed. Marcus Cunliffe [London: Penguin, 1973], 173-205, p. 195).

51. Carolyn Porter, “Absalom, Absalom! (Un)Making the Father," in The Ridge Companion to William Faulkner, ed. Philip M. Weinstein (Cambridge: Cambridge UP, 1995), 168-96, p. 179. 
nalysis in their readings, however, instead of the family romance fantasy they rely on the concept of Oedipalization, which I do not think can account for the crucial momentum of replacing the actual father with somebody more apt for the position.

In Sutpen's romance the vital turn takes place when his father sends him to that big house with a message to the plantation owner (229), but he is ejected by a "nigger" "even before he [had] had time to say what he came for" (188). "He never even remembered what the nigger said, how it was the nigger told him ... never to come to the front door again but to go around to the back. He didn't even remember leaving" (188). Many critics emphasize this incident at the mansion door as the central moment of his life, the "traumatic affront," ${ }^{2}$ which "puts an end to Sutpen's childhood,"53 determining the course of subsequent events. However, they attribute the "trauma" to different aspects and details of the incident: according to Patricia Tobin, it is caused by Sutpen's "recognition of his own anonymity"; 54 Adamowski states that, at the front door, in the other's gaze, Sutpen acquires a "sharp sense of himself as an object in the world, among other objects." 55 According to J. G. Brister, this is Sutpen's first moment of self-consciousness, of self-perception" resulting form "his feeling of racial 'otherness." " 56 He claims the encounter between Sutpen and the "monkey nigger" to be a replication of the Lacanian mirror stage, but, "in this case, the mirror is a racial 'other. " ${ }_{57} \mathrm{He}$ also argues that

Sutpen's sense of self is not born out of an identification with the white plantation owner ... but out of the realization of racial difference: fundamentally unaware of difference, Sutpen is awakened by his encounter with the black servant to the dialectic between oppressor and oppressed ..., between rich and poor, between self and other. This encounter ultimately leads to the revelation of the self he will become, of the patriarchal authority he will assume. 58

I consider all the above-mentioned arguments highly relevant; however, I would also add my, somewhat different, perspective to the picture. In my view, the ominous encounter is so traumatic for him because it mirrors those humiliating incidents which called forth his disillusionment in his father: the father's not being

52. Irwin, "Dead Father," p. 154.

53. Adamowski, p. 120.

54. Tobin, p. 109.

55. Adamowski, p. 120.

56. J. G. Brister, "Absalom, Absalom! and the Semiotic Other," Faulkner Journal 22.1-2

(2007) 39-53, p. 43

57. Brister, p. 43.

58. Brister, p. 44. 


\section{MÁRTA ASZTALOS}

allowed to enter the taverns through the front door and his being thrown out by a nigger once he tried to do so. Moreover, he comes to the big house in place of his father, as his metaphorical substitute, trying to speak the words of the father and all of a sudden finds himself "really" in his father's place, suffering weirdly similar humiliation to what the old man did. He is experiencing himself being "transformed" into his father, with whom he does not want to identify any more.

The humiliation at the front door functions as a trigger and determines the rest of Sutpen's life. He cannot pass that affront without determining to take revenge on the aggressor. However, instead of killing him, he rather chooses to identify with him:

He knew that something would have to be done about it; he would have to do something about it in order to live with himself for the rest of his life... He thought ... 'So to combat them you have got to have what they have that made them do what the man did. You got to have land and niggers and a fine house to combat them with. You see?' (189-90, my emphasis)

Thus, his romance culminates in the desire to create, to father himself59 by realizing his design outlined above. However, the term "his design" is not entirely appropriate, since he, driven by what René Girard terms mimetic desire, wants to copy an already existing pattern. His desire is a borrowed desire, like the Proustian snob's, who "slavishly copies the person whose birth, fortune, or stylishness he envies,"6o wanting to become his mediator, intending to steal from the mediator his very being. ${ }^{61} \mathrm{He}$ wants to reach autonomy and become origin-al through turning into a copy, thus losing his autonomy in fact. The failure of his self-fathering quest is, therefore, predetermined. Despite all his efforts, he can never get out of the symbolic paternal power structure, he can never free himself, as the design through which he wants to define and father himself is that of the ancestors, his desire is the desire of the Other. ${ }^{62}$

59. According to Freud, the desire to take his father's place and "to be his own father" (Sigmund Freud, "Dostoevsky and Parricide," in Standard Edition, Vol. 21, 173-96, p. 173) is the ultimate wish of the child in the family romance fantasy.

6o. René Girard, Deceit, Desire and the Novel: Self and Other in Literary Structure, trans. Yvonne Freccero (Baltimore: John Hopkins UP, 1984), p. 24.

61. Girard, p. 54.

62. According to Girard the desire of the snob and that of the child (puerile bovarysm) have much in common and work according to the same mechanism (Girard, pp. 35-36.). Apparently the concept of puerile Bovarysm/the Proustian snob's imitative desire may communicate with the Freudian idolization and mimesis of the father in the family romance in a fruitful way. 


\section{The Bastard's Romantic Family Romance: Charles Bon}

As Quentin recounts the story of Sutpen's second endeavor to accomplish the design, we reencounter the central dilemma of the novel, which has already been presented to us twice by the previous narrators but remained unsolved: the mystery of Henry's repudiation ${ }^{63}$ of his father for Charles Bon, and the reason of his murdering the very same man four years later. In Quentin and Shreve's interpretation, just as one would expect, paternal-filial conflicts are lurking below the surface here as well. Their "solution" of the dilemma comes in a rather unexpected fashion: they reveal Charles Bon to be Sutpen's firstbo(r)n, repudiated, part negro son seeking the acquaintance and recognition of his father. By doing so, they break away from Mr. Compson's love-triangles theory. In spite of this, many critics argue that Quentin and Shreve's story follows the pattern of a romantic love story, 64 a chivalric (or traditional medieval ${ }^{65}$ ) romance, celebrating the eternal verity of love, ${ }^{66}$ or as Donald M. Kartiganer claims: it is modeled after a Byronic romance. ${ }^{67}$

In partial agreement with these critics, I am inclined to say that Quentin and Shreve's story is organized around the problem of love, but the concept of love is radically different from the ones used by the previous narrators, or classical love stories. In Rosa's narrative, love means the "affection" of Bon and Judith; it is always used in reference to male-female relationships. Mr. Compson adds some more subversive colors to the concept, portraying Henry as cherishing incestuous desires for Judith and possessing brotherly love of such intensity for Bon that it borders on homoeroticism. In Quentin and Shreve's textual world, however, love gets a further meaning and connotation. When Shreve introduces the topic: "And now ... we're going to talk about love" (253, my emphasis), the reader, judging by the antecedents, (rightly) expects that $\mathrm{s} /$ he is going to read about the budding affection between the only hypothetical couple of the fiction. However, in spite of the fact that Shreve starts talking about Bon and Judith, his thoughts wander on, in search of a "more appropriate" love object. Judith as a love object, as a Platonic object of desire does not and cannot appear in Quentin and Shreve's version, as "desire exhibits a structure of the wish; it is based on the absence or privation of its object," 68 and she is portrayed as somebody always there waiting to be gathered:

63. Sutpen's only legitimate son, "so glib to the design" (Faulkner, p. 211.)

64. Adams, p. 181.

65. Levins, p. 43.

66. Levins, p. 42.

67. Kartiganer, p. 93.

68. Elizabeth Grosz, Jacques Lacan, a Feminist Introduction (London: Routlege, 1991), p. 64. 


\section{MÁRTA ASZTALOS}

She would be easy like when you have left the champagne on the supper table and are walking toward the whiskey on the sideboard and you happen to pass a cup of lemon sherbet and tell yourself. That would be easy too only who wants it ... besides knowing that that sherbet is there for you to take. Not just for anybody to take but for you to take, knowing just from looking at that cup that it would be like a flower that, if any other hand reached for it, it would have thorns on it but not for your hand. (258-59)

The Barthesian "staging of an appearance-as-disappearance"69 cannot even emerge, as the veil, which should cover the woman and is necessary for the operation of desire, is missing; she is there exposed: "He must have known all about her before he ever saw her - what she looked like, her private hours in that provincial women's world that even men of the family were not supposed to know a great deal about; he must have learned it without even having to ask a single question" (253).

Since Judith is not able to function as an object of desire, their attention shifts on to Henry, the other angle of Mr. Compson's incestuous love triangle. It is interesting to notice that they seem to take into consideration the solutions offered by the previous narrators, especially those provided by Mr. Compson, since he is the first one who tries to offer real solutions to the dilemmas. Henry, however, with "the eagerness which was without abjectness, the humility which surrendered no pride," with "the entire proffering of the spirit" (254) has also no chance to take the place of the object petit $a$, and thus needs to be discarded as well.

Through the brother's face, however, Shreve's attention shifts to the person who is the unapproachable, the unattainable entity per se, thus the perfect object of desire: the father of the illegitimate child:

I shall penetrate by something of will and intensity and dreadful need, and strip that alien leavening from it and look not on my brother's face whom I did not know I possessed and hence never missed, but my father's, out of the shadow of whose absence my spirit's posthumeity has never escaped.

In Sutpen's figure, they have everything together: the momentum of rejection in the past, the mystery of the unknown, heroic stature. The formula seems to work, since Bon's first utterances mentioning Sutpen as his father clearly designate him as the object of desire (object petit $a$ ) and bear strong resemblance to a declaration of love:

69. Roland Barthes, The Pleasure of the Text, trans. Richard Miller (New York: Hill and Wang, 1997), p. 10. 
"All right. I'll come home with you for Christmas," not to see the third inhabitant of Henry's fairy tale, not to see the sister because he had not once thought of her: ... but thinking So at last I shall see him, ... whom I had even learned to live without, ... Because he knew exactly what he wanted; it was just the saying of it - the physical touch even though in secret, hidden - the living touch of that flesh warmed before he was born by the same blood it had bequeathed him to warm his own flesh with.

(255)

In their version, Bon shows the slightest interest in the marriage with Judith only to get near Sutpen. The sole motivation behind all his actions is to get the recognition of his father: "that instant of indisputable recognition ... That's all I want. He need not even acknowledge me; I will let him understand just as quickly that he need not do that, that I do not expect that, will not be hurt by that, just as he will let me know that quickly that I am his son" (255). He is willing to subdue everything for that instant of acceptance, for "the living touch of that flesh" (255), which would provide him with a subject position in the world, which would inscribe difference into that "original undifferentiated stage before the emergence of subjectivity."7o In J. G. Brister's words, he desires the "castrating" touch of the father that would "hail him into the symbolic," that would "stabilize the drives that 'run hot and loud' in his body, that he may be castrated into the repressing patriarchal design." 71 His yearning for being named by the father, for "a sheet, a scrap of paper with the one word 'Charles' in his hand," also confirms this. Brister argues that his "unsymbolized" status is not only due to the lack of the Father in his life, but to his racial otherness and his resulting intimate relationship with the realm Kristeva calls the semiotic. "Bon represents the semiotic" in the world of the novel, while "Sutpen embodies the symbolic."72

His longing for objects like "a sheet, a scrap of paper with the one word 'Charles' in his hand... Or a lock of his hair or a paring of his finger nail" (261), on the other hand, also illustrate his wish to possess the object of his desire through possessing a partial object, a token. His behavior, the emotional stages he is portrayed as experiencing, closely resemble those of the yearning "lover": "suspense and puzzlement and haste," and later "passive surrender" (265). Taking all these into consideration, we can come to the conclusion that the Lacanian object petit a (autre/other) and Autre/Other coincide in his case, and the coincidence happens in a highly romantic overtone.

70. Doreen Fowler, "Revising The Sound and the Fury: Absalom, Absalom! and Faulkner's Postmodern Turn," in Faulkner and Postmodernism: Faulkner and Yoknapatawpha, ed. John N. Duvall and Ann J. Abadie (Jackson, MS: UP of Mississippi, 2002), 95-108, p. 103.

71. Brister, p. 48.

72. Brister, p. 47. 


\section{Another Romantic Family Romancer: Henry Sutpen}

In Shreve's version Henry is portrayed as nourishing similar affection towards Bon, whom he looks at as a "mentor" (254), a Father. He apes his clothing, his speech, his movements, everything about him, "completely unaware that he was doing" so (252). There is nothing Bon could not "do with this willing flesh and bone" (254), there is nothing he could not "mold of this malleable and eager clay which that father himself could not" (254). Moreover, as we have already learned from Rosa, when the time comes for Henry to choose between Bon and his father, 73 he formally abjures his father and renounces his birthright (62) for his chosen ideal. Moreover, his affection for Bon, similarly to that of Bon's for Sutpen, is also related with words that belong to the vocabulary of love: "We belong to you, do as you will with us" (262). "All right. I'm trying to make myself into what I think he wants me to be; he can do anything he wants to with me" (264). "Hers and my lives are to exist within and upon yours" (260).

Thus, the word "romance" seems to be highly relevant, though not in its "conventional" meaning. In Quentin and Shreve's narrative, "romance" and "love" are concepts which are always mentioned with reference to imaginary father-son relationships. In their world, love can be directed only towards an ideal father, an idealized hero ${ }^{74}$-such as Bon for Henry, or Sutpen for Bon. Hence, romance is relevant in the Freudian sense of the word. The Freudian family romance, however, acquires an additional "romantic" overtone.

\section{The Closure of the Romances}

In Sutpen's and Henry's cases, we can find all elements of the Freudian family romance: disappointment in the real father, choosing a surrogate father, idolizing and miming him. In Bon's case the situation is somewhat different, as his family romance seems to have undergone some curtailment. Being born a bastard, he does not need to imagine himself as such; having grown up without a father, he does not need to pretend not to have one. Thus, the usual first steps in his family romance are missing. Sutpen (who is his biological father "according to Shreve") refuses to fill that part, causing an absence, a lack. As the "knowledge of the father's empty

73. Henry chooses his ideal (Father) and turns away from Sutpen when Sutpen reveals to him the "truth" about Bon's descent and on account of that prohibits Judith and Bon's marriage.

74. Henry "looked upon Bon as though he were a hero out of some adolescent Arabian Nights" (Faulkner, p. 76). For the analysis of Bon's character as a Rankian hero see T. H. Adamowski's "Children of the Idea: Heroes and Family Romances in Absalom, Absalom!". 
place ... constitutes desire itself," 75 the figure of the biological father, in this case, may become the Girardian mediator, ${ }^{76}$ and the object of desire, thus, the ideal father of the family romance. 77

However, Henry's fratricide, triggered by Sutpen's uncovering the secret of Bon's "negro" descent, brings about a tragic closure of all the hitherto mentioned family romances. Le non du pére pronounced to Henry by Sutpen ${ }^{78}$ prohibits incest and miscegenation and reestablishes Sutpen's paternal authority over his legitimate son. Henry kills Bon, his "ideal" father, obeying his biological father's order and, thus, reintegrating himself into the Law of the Father. Bon is to die without his father's recognition. His quest is destroyed; he cannot become a son, a subject: he has to remain a bastard, a non-subject, a non-entity, a "de-sign." Turning his only legitimate son into a murderer, an outlaw; Sutpen loses his only chance of accomplishing "his design." Thus, he is not able to become his own father, as the son able to make a dynastic father out of him is destroyed. What is more, after a last failing attempt to father a son with the fifteen-year-old Milly Jones, Sutpen dies at the hands of Wash Jones - a drunkard - who closely resembles Sutpen's own father. Therefore, all filial quests fail, all three sons (Bon, Henry, and Sutpen) are retracted by their origins, and the romances relapse back to their starting points.

At this stage the following questions arise: if Quentin and Shreve want to "get even with," or walk out of paternal authority by telling this story, why do they construct filial tragedies and family romances destined to fail? Why do they choose to enter a game they have already lost even before entering? Is it lost at all?

If we regard Quentin's story as a family romance on the level of the narrative text, aiming at self-fathering through the construction of a narrative, working better than his own father's did, the formation of filial tragedies should not necessarily mean the tragedy or fall of Quentin (and Shreve). Provided that they were able to come up with a neat, well-constructed narrative; they could successfully overwrite the paternal metanarrative and beat paternity "on home ground," especially because Mr. Compson's narrative, as many critics have pointed out, lacks ground: there are too many gaps, too many inexplicable incidents attributed to the caprice of fate. Let us see now if their family romances can prove to be more "successful" on the level of the narrative text than on the level of the story, if they are able to fulfill the expectations attached to them and can become the means of Quentin's self-fathering.

75. Robert Con Davis, "The Discourse of the Father," in The Fictional Father: Lacanian Readings of the Text, ed. Robert Con Davis (Amherst: U of Massachusetts P, 1981), 1-26, p. 9.

76. Girard introduces this term for the model who determines or seems to determine the object to be pursued for the disciple (p. 2).

77. Sutpen is also Lord of the Manor; his figure complies perfectly with the Freudian model.

78. "He must not marry her" (Faulkner, p. 283; my emphasis). 


\section{Narration as a Family Romance}

Sutpen's story is recounted by Quentin, but, according to him, it originates from his Grandfather, to whom Sutpen himself " 'told ... about it' ... 'when the architect escaped" " (177). Narrating Sutpen's story, Quentin constantly uses him as a point of reference, trying to prove the authenticity of the story. His narrative is scattered with references such as "he told Grandfather" $(177,178,180,181,182,183,184,186$, 193, 195, 200, 203, 208), "he remembered" (181, 182, 183, 200, 201, 207), "[t]hat was how he [Sutpen] said it" (193), "[t]hat was how he told it" $(181,204)$. Thus, at the beginning of his narrative, it is the Name-of-the-Father that corroborates the story, that keeps it together, functioning as the focal point, as a Lacanian point de capiton. At certain points, however, these references are overused to such an extent that some suspicion rightly arises in the reader that they might be trying to hide something or make up for the lack of something.

Moreover, the reader may notice some "uncanny" elements in the story of Sutpen's life, in his portrayed behavior, which can be weirdly familiar from earlier points, or, to be more precise, from Quentin's earlier behavior. The child Sutpen's split consciousness in the cave - the image of someone arguing with oneself about something - may ring a bell from the beginning of the novel, where Quentin is portrayed in exactly the same manner: "he would seem to listen to two separate Quentins now - ... - the two separate Quentins now talking to one another in the long silence ... It seems that this demon - his name was Sutpen - (Colonel Sutpen) - Colonel Sutpen ..." (5). These signs may indicate that he weaves the story after his own fashion; that his Sutpen acts, feels, and talks like Quentin would in a similar situation.

Quentin's changing the references used in his narrative also illustrates that as he gets into the swing of storytelling, he forgets about anchoring his narrative in the past. To be more precise, the gesture remains, but the introductory verbs of his indirect speech go through an alteration, mirroring a change in his narrative attitude. In the first half of his narration, he uses verbs of mediation or reporting - such as say, remember, or tell - which, by referring to Sutpen's actual speech act, keep his position as the origin, the source of the story intact. However, after a certain point, Quentin starts using verbs of mental activity - know, think, and see - and via these, slips into Sutpen's character: he knows, remembers, and sees in lieu of him. Hence, he becomes active in the creation of the story, not being content with the role of the mouthpiece. Gaining confidence as a narrator, he starts seizing authority over the/his story, venturing out from the camouflage of the ancestors for some moments. However, the reader can also observe the countermovement when Quentin loses ground and falters in the narration. " 'He went to the West Indies.' Quentin 
had not moved, not even to raise his head from its attitude of brooding bemusement. . 'That was how Sutpen said it'" (192, my emphases). This is a point of rupture after which he is spectacularly unable to continue the story. He tries to gain some time by depicting how Sutpen told it, from at least three different perspectives, bracing himself to go on, but he gets stuck at the very same point each time he tries to continue. The reader can easily trace his struggle: the same or very similar versions of the above quote are uttered four times in two pages. " "He just said, "So I went to the West Indies," ' "(193) "'telling Grandfather ... "So I went to the West Indies" ' " (194). But for his brooding, he does not manage to come up with a creative continuation. Finally, he tries to solve the problem by claiming that Sutpen did not tell "how he got there, what had happened during the six years between the day he had decided to go to the West Indies and become rich" (199). Thus, we can see that the moment Quentin's creativity and narrative talent falter, he returns to the Father's shadow, claiming emphatically that the discrepancy is Sutpen's or his Grandfather's fault: "that was how he [Sutpen] said it" (193), "[t]hat was how Grandfather remembered it" (198). He puts the blame for the narrative's lack of regard for "logical sequence and continuity" (199) on Sutpen, trying to keep the illusion of "truthfulness."

Quentin is still in the middle of depicting Sutpen's hypothetical musing about the inscrutability of his fate, when Shreve - tired of Quentin's fiddling about with trivia, and his dragging the story on without slight amount of development - leaves the room for some time, and then returns, flinging the "joker" onto the table with a graceful move.

He did not say Wait, he just rose and left Quentin sitting before the table, the open book and the letter, and went out and returned in the robe and sat again and took up the cold pipe, though without filling it anew or lighting it as it was. "All right," he said. "So that Christmas Henry brought him home, into the house, and the demon looked up and saw the face he believed he had paid off and discharged twenty-eight years ago. Go on."

(213; my emphasis)

Thus, refuting the common critical (mis)conception79 that this radically new information is introduced by Quentin, we have to notice that it is Shreve's creation, who, by this act of intrusion into the narration, sets absolutely new rules for the "game." Shreve takes the step that Quentin was reluctant or unable to: to step out from the shadow of the fathers, to exercise the potential creativity and freedom, which is within the power of the storyteller. By doing so, he gives an impetus to the

79. Lind, p. 896. 
so far jolting narration. At this point, it becomes clear for the reader that Shreve's previous urging, sometimes impatient gestures - "'All right. Don't bother to say he stopped talking now; just go on.' ... 'Just don't bother,' ... . 'Just get on with it'" (208, my emphases) - also try to persuade Quentin to stop wasting so much time and energy on making the story look faithful to those of the fathers. Shreve encourages him instead to take over the narration from the ancestors not only apparently, but in reality as well.

In spite of Quentin's "Yes," (210), which is probably meant not only as the verification of Shreve's statement about Bon's descent, but also as the acceptance of the new rules; he does not quit his previous narrative strategies. He imports the new information provided by Shreve into the story, but keeps referring to the ancestors as its source; what is more, he cites both his father and his grandfather just to make sure: "Father said he probably named him himself. Charles Bon. Charles Good. He didn't tell Grandfather he did, but Grandfather believed he did, would have” (213). At this point, however, we can observe Shreve's taking up the function of the catalyst, as he does not leave it at that, he does not let Quentin get away with such a striking inconsistency, but forces him to rectify, to get it straight:

"Your father" Shreve said. "He seems to have got an awful lot of delayed information awful quick... . If he knew all this, what was his reason for telling you that the trouble between Henry and Bon was the octoroon woman?"

"He didn't know it then. Grandfather didn't tell him all of it either, like Sutpen never told Grandfather quite all of it."

Shreve persists until he forces Quentin to come out from the shadow of the fathers, to undertake the place of the narrator with all its hardships, risks, setbacks, and possibilities (self-fathering).

"Then who did tell him?"

"I did." Quentin did not move, did not look up while Shreve watched

him. "The day after we - after the night when we - " (214, my emphasis)

With this "I did," Quentin takes over the responsibility of accounting for the newly imported information (Bon's descent) from Shreve. However, since Quentin is not able to come up with a meaningful rationalization, it is Shreve again who offers the solution, gallantly making it appear as if it came from Quentin: "'Oh,' Shreve said. 'After you and the old aunt. I see. Go on. And father said -' " (214, my emphasis). Having offered the decisive piece of information again, and having 
set up a game of provocation, Shreve withdraws to the background ${ }^{80}$ to let Quentin fight his battles.

As the narration proceeds, however, this separation resolves, the manner of storytelling is transformed: Shreve also takes a more active part in story-weaving; it becomes more and more difficult to tell the narrative voices apart. "It was Shreve speaking, though ... it might have been either of them and was in a sense both: both thinking as one..." (243). The narrative soon starts working as a duet, as "some happy marriage of speaking and hearing" (253), both of them being Henry Sutpen, and both of them being Bon, compounding each of both yet neither (280). Their narration starts functioning as the "other," the counter-discourse of the realistic "patrilinear" narrative tradition: it operates according to different rules. They do not "remember" and "recollect" any more what the ancestors said, but they "believe" (267), "invent" (268), and sometimes "dont [sic] know" (259). They turn to inventing the story instead of relating it. Their mutual aim is to create "between them, out of the rag-tag and bob-ends of old tales and talking, people who perhaps had never existed at all anywhere" (243), to tell a story which is "probably true enough" (268, my emphasis). However, true here does not mean corresponding with something "outside," being true to historical facts and thus being "realistic;" but it is defined "inside" this paradigm, constructed by the two of them. Their concept of "true" means "fit[ting] the preconceived" (253).

Accepting Shreve's idea that he (Quentin) got hold of the decisive information when he went to Sutpen's Hundred with Rosa, Quentin shifts the most important point of reference, the one which keeps the structure of the story together, the Lacanian point de capiton from the figure of Sutpen (and Grandfather and Father) to the night incident about which the reader has learnt little so far. Thus, the point of reference, the "preconceived" pillar of their story is projected ahead to the point where their narrative reaches this past incident. By this, the disclosure is postponed, and Quentin gains some more time to "brood" over the solution.

“And when your old man told it to you, you wouldn't have known what anybody was talking about if you hadn't been out there and seen Clytie. Is that right?"

"Yes," Quentin said. "Grandfather was the only friend he had."

“The demon had?” Quentin didn't answer, didn't move. . . paid no attention whatever. . . his face still lowered, still brooding. . . ${ }^{81}$

8o. If we consider that Shreve's name closely resembles the word to shrive, meaning to hear somebody's confession, we can say that this behavior fits the task.

81. The verb brood is frequently used in reference to Quentin's narrative effort. If we take into consideration that it originates from the verb breed, it also backs up the theory that Quentin's unconscious motivation of storytelling is self-fathering (my italics in citation). 


\section{MÁRTA ASZTALOS}

The story of the night incident is recounted only when it cannot be put off any longer, at the very end of the narrative. It is Shreve again who pushes Quentin to reveal the mystery of his knowledge and understanding, extracting the climax of Quentin's romance: "You dont [sic] know. You dont [sic] even know about the old dame, the Aunt Rosa" (289).

The tension gradually increases as they get nearer and nearer to the hidden secret of Sutpen's Hundred: Henry Sutpen, who has been hiding there for four years. He is the living past who is in on all the secrets, the meeting with whom has been designated as the source of Quentin's supposed understanding of the Sutpen drama: “'you wouldn't have known what anybody was talking about if you hadn't been out there" "(220). The relation of their meeting is supposed to justify their narrative retrospectively. "We have been prepared for it as a climactic moment of understanding." ${ }^{2}$ By this act of justification and ratification, their narrative would be able to reach a coherent formal pattern, and via that, could become "true," could be accepted as (the Sutpen family) "history," and could take the place of the incoherent paternal master-narrative(s). However, the designated point of reference is empty. No meaningful or relevant information gets transferred between them:

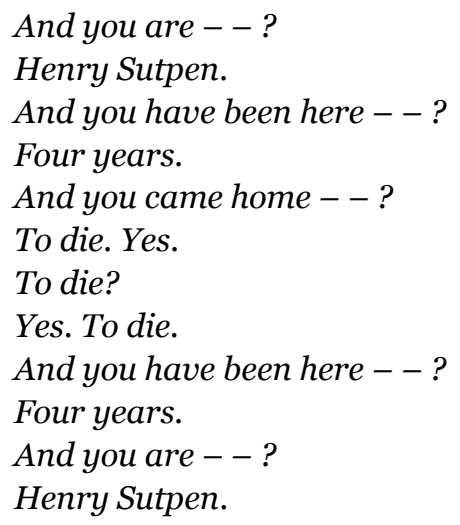

As Peter Brooks puts it "the passage reads nearly as a palindrome, virtually identical backward and forward, an unprogressive, reversible plot" (264), which provides no kind of information about the mysteries. Thus, I would argue, it is unable to function as the verification of Quentin's narrative. It signifies the collapse of the sons' narrative, which was standing on this "pillar," thus denoting the failure of their quest for narrative authority, for "self-fathering."

82. James Guetti, "Absalom, Absalom! The Extended Simile," in The Limits of Metaphor: A Study of Melville, Conrad, and Faulkner (Ithaca, NY: Cornell UP, 1967), 69-108, p. 99. 
In spite of the fact that Peter Brooks also identifies the palindrome as "a kind of hollow structure, concave mirror or black hole at the center of the narrative," ${ }_{3}$ he does not recognize this moment as the one proving Quentin wrong and denoting the failure of his hermeneutic quest. This is due to the fact that Brooks designates a different incident as the source of Quentin's understanding of the Sutpen drama: "the discovery of a certain formal pattern of the crossing of categories: Clytie's Sutpen face with its negro pigmentation, the very design of debacle." 84 Moreover, he elevates Clytie to be a "hermeneutic clue" in the novel. This does not mean that Brooks is happy with the narrative design of the younger generation. He, however, assumes that the problem lies elsewhere: the story of the House of Sutpen as told by Quentin and Shreve, according to Brooks, seems to be caught between two figures: on the one hand, incest, "which overassimilates, denies difference, creates too much sameness"; 85 on the other hand, miscegenation, "which overdifferentiates, creates too much difference, sets up a perpetual slippage of meaning." The two young men are "never able to interweave them in a coherent design" (266). "Incest and miscegenation, sameness and difference ... fail to achieve a pattern of significant interweaving ... the tale can never be plotted to the final, thorough Dickensian accounting" (266); there is a residual meaning embodied in Jim Bond, who seems to be "the very principle of nonsignificance" (266).

At this point, it is also worth having a look at how other critics evaluate Quentin's endeavor or achievement: T. H. Adamowski states that “Quentin's own heroic adventure, his decision to climb the old Sutpen staircase and look into the bedroom ... allows him to overthrow his own father, or at least reject Mr. Compson's interpretation of the Sutpen disaster." 86 John T. Irwin also considers Quentin's accomplishment as a narrator a success:

In the struggle with his father, Quentin will prove that he is a better man by being a better narrator - he will assume the authority of an author because his father does not know the whole story, does not know the true reason for Bon's murder, while Quentin does.... Moreover, in terms of the narrative act, Quentin achieves temporal priority over his father, and within the narrative Quentin takes revenge against his father, against time, through a substitute. ${ }^{87}$

83. Brooks, p. 264.

84. Brooks, p. 259.

85. Brooks, p. 265.

86. Adamowski, p. 127.

87. John T. Irwin, "Repetition and Revenge" in William Faulkner's Absalom, Absalom! A Case Book, ed. Fred Hobson (New York: Oxford UP, 2003), 47-69, p. 64. 


\section{MÁRTA ASZTALOS}

However, the question rightly arises: If Quentin's endeavor was successful, if he managed to "overthrow" 88 his father, "prove that he is a better man by being a better narrator," or "achieve temporal priority" 89 over him; why would he "conclude" his narrative with the following words: "Nevermore of peace. Nevermore of peace. Nevermore. Nevermore" (298).

His physical appearance also leads me to somewhat different conclusions. He is lying on his back "still and rigid ... with the cold New England night on his face" "his eyes wide open" (298), like somebody dead but still breathing, his soul haunted, tortured by some unknown restlessness or anxiety.

If we look at the dialogue from another perspective, it can provide us with the clue to the failure of their narrative. Henry and Quentin's supposed conversation is not only a palindrome but a circular, reclinate structure, which returns to the exact point where it began. As we have seen before, circular structuring is one of the main characteristics of Mr. Compson's paternal narrative, providing the reason for his story's appearing to be so fatalistic. He almost always starts with the final scene, the outcome, and portrays the events leading up to it later. Quentin also takes over this structuring principle, as it is traceable at several points in his narrative; for example, in the story of Sutpen, where they start with the final scene, his murder, and then relate his life story in detail, only to get back to the murder again in the end of Chapter VII. This, in other words, means that he also falls victim to the Girardian mimetic desire, which seems to be contagious among the sons in the novel - Sutpen miming an already existing design (the design of the plantation owner, his ideal father), Henry miming Bon's behavior and style. This understanding can also give us a possible explanation for the highly interesting romantic overtone of Quentin and Shreve's family romances as well. They come up with new, crucial pieces of information, providing their characters with new motivations for their deeds and granting a different pattern of logic to the events of the plot. However, they keep certain elements of the father's narrative, like the overtly romantic tone and the pattern of "love"-triangles driven by desire. Family romance also has a triangular structure (driven by desire) with the son in one angle, the father to be replaced and the ideal father in the other two.

This puts Quentin's failure as a narrator into a new light as well. Being left on his own, he is not able to come up with an origin-al solution, to become the origin, the father of the story; but, like Sutpen himself, he looks to the outside, to a/the father for a design. He copies and repeats the design (and the mistake) of the father, drowning his narrative in circularity, in mimetic desire turning against itself.

88. Adamowski, p. 127.

89. Irwin, "Repetition," p. 64. 